\title{
UNHCR and the Status of Prima Facie Refugees in Kenya
}

JENNIFER HYNDMAN* \& BO VIKTOR NYLUND $†$

\section{Introduction}

In the recent past, the Office of the United Nations High Commissioner for Refugees (UNHCR) has experienced novel situations which have challenged its very mandate. Responding to needs for protection and assistance generated by mass displacement on an unprecedented scale has pushed the agency's scope to new limits. At the same time, UNHCR has expanded its roles to deal with emerging crises of displacement where States that are signatories to international refugee law and human rights instruments have failed to meet their obligations. The situation is becoming legally more complex and incomplete, as displaced persons no longer fit the traditional definitions of a refugee. As refugee resettlement numbers in receiving countries like Canada and the US decline, we suggest that particular patterns of 'ordering disorder' have emerged.' Increasing reliance on multilateral agencies such as UNHCR to deal with humanitarian crises by individual States has been observed. The UNHCR itself says that the organization 'has been transformed from a refugee organization into a more broadly-based humanitarian agency." The agency's focus has broadened to meet the exigencies of current political crises, yet the bases and parameters for such change are not clearly defined:

* Jennifer Hyndman worked for UNHCR as an Associate Field Officer in Somalia, 1993. In 1994-95 she conducted research in the Dadaab camps and at UNHCR's Nairobi Branch Office. Currently, she is an assistant professor at Arizona State University, West Campus.

† Bo Viktor Nylund worked as a UNHCR Associate Protection Officer for 2 years at Branch Office Nairobi, 1994-96. He has since completed an LLM. from Columbia University, and currently works for UNICEF as the Humanitarian Principles Project Officer. The authors would like to thank Kate Balian and Nadine Schuurman for their comments on eartier drafis of this paper. The views expressed in this paper are those of the authors, and are not necessarily shared by UNHCR, UNICEF or the United Nations.

1 US resetulement numbers for Africa have remained constant at 7,000 annually, despite a significant decline in resetdement totals since 1992/93.

2 UNHCR, The State of the Worlds Refuges: In Search of Salutions, (Oxford: Oxford U.P., 1995), 48. 
The world's most powerful States and the United Nations itself have been placed in a considerable dilemma by the rash of internal conflicts and humanitarian emergencies since the demise of the bipolar State system. While the old rules of the game have evidently changed, the international community has found it extremely difficult to articulate a coherent set of principles and practices which are geared to contemporary circumstances. ${ }^{3}$

In the absence of a coherent set of principles and practices for current crises of displacement, this paper explores some of the ad hoc strategies employed to assist refugees, as the UNHCR adjusts to its expanded role. The reason why UNHCR is facing new challenges is, of course, linked to developments in the international arena, where internal struggles and civil wars become increasingly common. Many such situations give rise to large movements of people; two main groups of displaced can be identified: internally displaced persons and prima facie refugees. Here, we examine some of the measures employed to 'order disorder' in the case of mass displacement. In particular, we are concerned with the use and arguable abuse of prima facie refugee status as a tool in managing large movements of displaced persons who cross international borders. Having both worked in Kenya with refugees, we focus on this case specifically.

The restricted mobility and entitlements of prima facie refugees are discussed in the context of the camps as 'temporary' solutions. One objective is to reiterate and analyse a question already posed by UNHCR, '(h)ow temporary is temporary?"4 The agency knows that 'these strategies (accommodating refugees in isolated camps, barring them from employment, etc.) are likely to prove politically unacceptable if maintained over an extended period of time.' The question we then pose is, 'when does such the short-term solution of placing prima facie refugees in a camp cease to be acceptable?' At what point do civil and political, economic, social, and cultural rights outweigh the privileges of safety against forced repatriation? While we do not offer a conclusive answer, these questions are crucial for refugee administrators, policy-makers, governments, and scholars to address. The current trend towards containing prima facie refugees, in countries like Kenya, will otherwise deepen.

After some introductory remarks relevant to refugees in the current context, a sketch of the situation for refugees in Kenya is presented. The Kenyan Government's acceptance of forced migrants from neighbouring countries over the past five years is qualified by its policy of isolating these prima facie refugees in remote desert camps where their mobility and access to employment are restricted. Following the sketch of refugees in Kenya, we focus on prima facie status itself. By tracing the history of

${ }^{3}$ Ibid., 115.

4 Ibid., 88; Jennifer Hyndman, 'The State of the World's Refugees - A Review Essay', 8 IJRL 276 (1996). 
prime facie status in Africa, we illustrate that the original intent and meaning has changed significantly since its inception. As civil conflicts continue in the Horn of Africa, some war-torn communities remain unsafe for refugee return. And yet, there are few permanent solutions practically available to refugees in camps. They have little choice but to endure the temporary arrangement of the camps, where they are dependent on the support of the international donor community, or to find refuge and livelihood elsewhere.

Moving between the Kenyan situation, in particular, and the evolving meaning of prima facie status more generally, we reiterate and pose further directions for practical change and further research in the final part of the paper.

\section{Refugees in Kenya}

Of the 27.4 million refugees and other persons of concern counted at the end of 1995, 11.8 million lived in Africa alone. ${ }^{5}$ The generous flow of humanitarian capital into Africa in the form of peacekeeping and refugee relief to support temporary solutions (that is, protection and assistance in camps) and to effect, at least in theory, more permanent solutions is impressive. The number of permanent solutions found for refugees and displaced persons who cannot return home remains, however, unimpressively few. ${ }^{6}$

Kenya is in the unenviable position of sharing borders with no fewer than five other nations, all of which - with perhaps the exception of Tanzania - have generated sufficient internal conflict to produce asylum seekers in Kenya. During the peak of refugee displacement in 1992, there were some 420,000 refugees in Kenya. ${ }^{7}$ Most refugees came as a result of internal disturbances and ethnic conflicts in neighbouring Somalia, Ethiopia, and Sudan.

The largest flow of refugees into Kenya has come from Somalia. In 1992, several hundred thousand refugees from Somalia began pouring over the border into Kenya's Northeast Province as civil conflict in Southern Somalia intensified. Widespread famine and the collapse of the Somalian State exacerbated this situation in which an estimated 500,000 Somali citizens died. Well over a million Somalians were internally displaced and some 600,000 fled the country, many of them seeking asylum in nearby Kenya and Ethiopia. While they were not warmly

5 UNHCR, 1995, above note 1.

${ }^{6}$ For further illustration and discussion of the dedine in refugee resettlement opportunities, see J. Hyndman, 'Geographies of Displacement: Gender, Culture, and Power in UNHCR Refugee Camps, Kenya', Ph.D. Disserration, Dept. of Geography, University of British Columbia, Sept. 1996.

7 US Committee for Refugees, World Refuere Surng 1996, (Washington D.C., 1996). 
welcomed in Kenya, the Government was obliged to accept them, partly because of its commitment in international law to the 1951 Convention and the 1967 Protocol relating to the Status of Refugees as well as the OAU Convention, and partly because it needed the continued support of donor countries - many of which had suspended foreign aid to Kenya at that time. While donor countries awaited a satisfactory outcome of the country's first multi-party elections before reconsidering their aid commitment to Kenya, President Daniel Arap Moi grudgingly allowed Somali refugees into Kenya on the condition that they reside in border camps. Continued capital flows of development aid from Europe and North America to Kenya were conditional upon a proven commitment to democratic process and upon the country's acceptance of Somalis in need of humanitarian assistance, some of which would no doubt benefit Kenya. In 1992 and 1993, UNHCR spent US $\$ 40$ million to establish refugee camps and border sites in Kenya. Today, Somali refugees still represent by far the majority of refugees in the country. While many do not live in camps, those who do reside in Ifo, Dagahaley, and Hagadera, near the town of Dadaab (see Figure 1).

After the fall of Ethiopian President Mengistu in May 1991, Kenya received students, military, and civilian refugees. Fighting in the Sidamo region of Ethiopia in 1992 created famine conditions in Southern Ethiopia and generated an influx of refugees to Northern Kenya early that year. While Kenya hosted more than 40,000 Ethiopian refugees in 1992, the number remaining in 1996 was just 5,000. The UNHCR closed its primary camp for Ethiopians, Walda, in 1993; most now stay in Ifo camp near the Kenyan-Somalian border.

In Sudan, conflict between government troops of the National Islamic Front (NIF) and the South's Sudanese People's Liberation Army (SPLA) and its offshoots continues after almost thirteen years. In 1996, some 4 million people were internally displaced within Sudan and 465,000 people were refugees in neighbouring countries. ${ }^{8}$ The vast majority of Sudanese refugees are living in Uganda, but some $\mathbf{4 0 , 0 0 0}$ have prima facie status in the Kenyan camps of Kakuma and Ifo.

\subsection{UNHCR's Cross-Border Operation}

Less than a week after President Moi won the Kenyan election in December 1992, he announced that refugees would be sent back to Somalia immediately. Having expressed this sentiment earlier, in August 1992, he now had the diplomatic and political power to withdraw some of his support for Somali refugees in the country. Meanwhile, at the request of the UN Secretary-General, UNHCR initiated the Cross Border Operation $(\mathrm{CBO})$ inside Somalia in order to stem the flow of refugees

${ }^{8}$ US Committee for Refugees, World Regugee Surnog 1996, above note 7. 


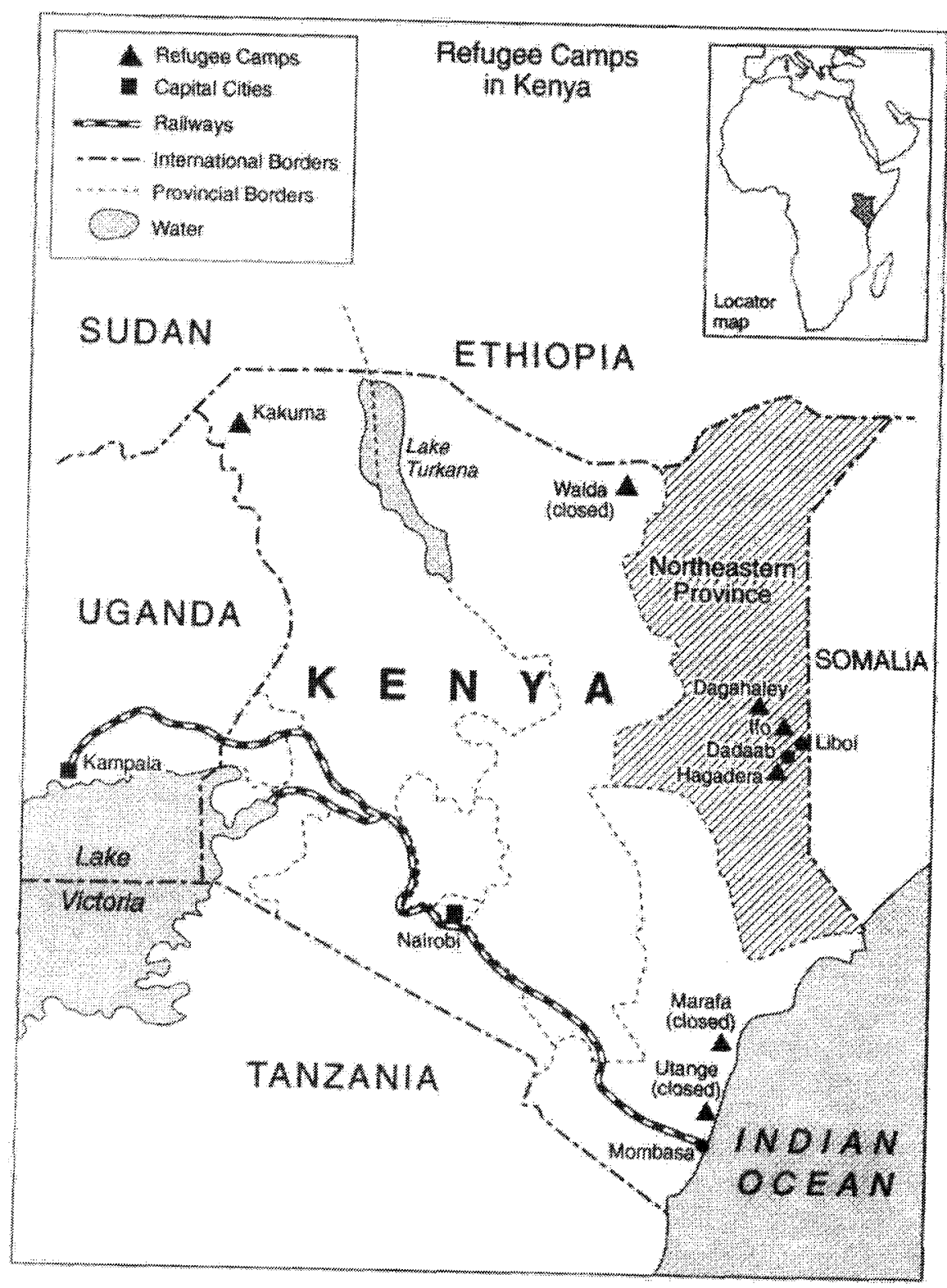

Figure 1 
from Somalia to Kenya and to entice those refugees already in Kenya to come home. Without President Moi's support, UNHCR could not assist and protect refugees within Kenya on the same scale within Kenya and so sustained efforts to fund CBO ensued. The idea was to invest in community rehabilitation in Southern Somalia so to encourage refugee repatriation to Somalia, and thus resolve the problem. UNHCR headquarters in Geneva established the Special Emergency Fund for the Horn of Africa (SEFHA) and began a major fund-raising effort in Geneva among donor countries to finance the Cross Border initiative. To cover the anticipated costs of repatriation, US\$5.5 million was requested. UNHCR appealed for another US\$13 million for CBO.

The Cross-Border Operation was significant in that it created a 'preventive zone' to dissuade further asylum seeking on the part of Somalians and to persuade Somali refugees in Kenyan camps to return home. ${ }^{9}$ Such measures have been used in other conflict zones where UN protected areas, safe havens, and humanitarian corridors have been designated as safe spaces for internally displaced persons (IDPs). We are thinking here of the 'safe havens' created for Iraqi Kurds, the 'zones of tranquillity' established for returning Afghan refugees, the 'open relief centres' set up for would-be Sri Lankan refugees, and not-so-safe havens of Srebrenica and Zepa in Bosnia and Herzegovina during the summer of $1995 .{ }^{10}$ While the idea of creating safe havens is not new in international humanitarian law, preventive zones and safe areas are arguably part of a new genre of post-Cold War humanitarian operations which emphasize assistance and protection of IDPs within conflict zones. " This shift also signals new meanings of 'temporary' and of prima facie refugee status for those who are not internally displaced.

Returning to Somalia, UNHCR established four outposts in Southern

\footnotetext{
While there was no formal security component to the $\mathrm{CBO}$, it would not have taken place without the presence of US/UN peacekeepers in the area.

10 Bill Frelick, 'Preventing Refugee Flows: Protection or Peri'' in US Committee for Refugees, World Refugee Serog 1993 (Washington, D.C., 1993).

11 As far as the legality of the protection of the internally displaced goes, for UNHCR to become involved there are a number of prerequisites: that there is a request from the Secretary-General, the General Assembly, or another competent organ of the UN, that the host country has requested UNHCR's intervention, and that the UNHCR itself is willing to become involved. A similar framework to the one dealt with in this paper has been advocated on behalf of the internally displaced by Dr Francis Deng, Special Representative of the Secretary-General on Internally Displaced Persons: "It must be expected that the definition of "internally displaced person" will be used in a variety of contexts to assign rights and responsibilities to individuals and authorities. Since action taken in the context of law must be comprehended and pursued with due regard to its implications for the assignment of rights and responsibilities, and, in the case of internally displaced persons, to specific functions of the international community in protecting them, the definitions should maintain a degree of flexibility and allow for prima facie recognition of a declaratory nature. Enumeration of causes should be indicative rather than exhaustive. At the same time, a definition should achieve a sufficient degree of precision in conformity with the principle that subjects of the law must know how to behave both in terms of rights and duties (emphasis added).' Sec report on Internally Displaced Persons: UN doc. E/CN.4/1995/50 para. 124.
} 
Somalia as part of the Cross Border Operation. The distance between the Kenya-Somalia border and the outposts, located a few hundred kilometres inland along the Juba River, circumscribed the 'preventive zone.' Considerable sums of money were invested to orchestrate the preventive zone. More than twenty NGOs were hired by UNHCR as partners in the CBO initiative, which included 'quick impact projects' (QIPs) to rehabilitate local towns and villages. These projects, which aimed to help communities resume a normal life after the devastation of war had a funding ceiling of US $\$ 50,000$ per project, though most amounted to far less than this. In 1993, a total of 320 QIPs were recorded as part of Cross Border Operations. ${ }^{12}$

By June 1993 some 30,000 Somali refugees had returned home to Somalia from Kenya - 12,000 of these with the help of UNHCR. ${ }^{13}$ The 285,000 Somali refugees remaining in the camps at that time were considered potential returnees until peacekeeping operations in Somalia went seriously awry.

As civil war continued to ravage large parts of Somalia in 1992, observers outside the country watched the politically-induced famine take its toll on much of the civilian population and declared Somalia a country in anarchy, unable to rule its own affairs. This thinking gave rise to UN Security Council resolution 794 which authorized a Unified Task Force (UNITAF) comprised of thousands of peacekeeping troops to enter Somalia to ensure the delivery of relief supplies. 'Operation Restore Hope', as the mission was called, was the first peacekeeping operation which intervened in a sovereign member State when that State did not present a military threat to its neighbours. ${ }^{14}$ Reports that more journalists than soldiers took part in the amphibious landing of US Marines just before Christmas 1992 speak to the popularity of the Somalian cause and international awareness of the humanitarian tragedy it represented. Operation Restore Hope was an experiment in post-Cold War humanitarian intervention on a global scale.

The US Marines were replaced by a UN peacekeeping force UNOSOM $\Pi$ - in May 1993. The UNOSOM II operation cost sponsoring governments US $\$ 1.5$ billion during its first year of operation. On the non-military side of humanitarian intervention, UN agencies proposed a 10-month budget for relief and rehabilitation in 1993, to the

\footnotetext{
12 Netherlands Development Corporation, 'Humanitarian Aid to Somalia, Evaluation Report 1994', Den Haag, 1994.

13 UNHCR, The State of the World' Refugeas: The Challange of Arotection, (Toronto, Penguin, 1993).

14 Samuel Makinda, Sceting Patce From Cheos: Humoritarian Intervention in Somalia (Boulder/London, Lynne Rienner Publishers, 1993). However, a threat to international peace and security is still a prerequisite for action under Chapter VII of the UN Charter, and identified in resolution: "[e]ndorses the recommendation by the Secretary-General in his letter of 29 November 1992 (\$ $/ 24868)$ that action under Chapter VII of the Charter of the United Nations should be taken in order to cstablish a secure environment for humanitarian relief operations in Somalia as soon as possible.'
} 
tune of US\$166 million. More than fifty international NGOs, funded principally by the UN, operated in Somalia during that year. However, in June 1993 the popularity of Somalia as the destination for millions of dollars in humanitarian assistance began to decline. The ambush and murder of fourteen Pakistani UN peacekeepers was considered retaliation by faction leader, Mohammed Farah Aideed, for a UNOSOM II weapons sweep in the Mogadishu neighbourhood he controlled. A UNOSOM II air attack in Mogadishu was launched to bring Aideed to justice. Unfortunately it also targeted a number of Somali civilians who were killed, an event which severely damaged the reputation of UNOSOM II in Somalia as a humanitarian peacekeeping force. The death of eighteen American soldiers later in 1993 adversely affected the popularity of the Somali cause abroad. Time magazine ran a photograph of one dead American soldier being paraded around the streets of Mogadishu by antiUN Somalian protesters. Before long, funding for humanitarian projects in Somalia began to decline dramatically, and in March 1995 UNOSOM II withdrew from Somalia altogether.

The point of recounting this short history of the Somalian crisis is to illustrate the rise and fall of its popularity with international donors. Billions of dollars were spent on peacekeeping and relief, as well as rehabilitation activities, to address the consequences of civil war in that country, illustrating the critical link between political will and effective humanitarian response. The demise of Somalia's popularity has made it increasingly difficult to raise funds for on-going international humanitarian activities in that country. In Kenya, however, the needs of refugees in camps - Somali, Sudanese, and Ethiopian - are perceived, in comparison, as less politically problematic. Funds have continued to flow to UNHCR's Branch Office in Nairobi for 'care and maintenance' functions in the camps. At the end of 1995, the majority of Somali refugees were housed in three camps - Ifo, Hagadera, and Dagahaley - near the Kenyan-Somalian border. Somali camps that were established in 1992 remain a temporary solution in 1997.

Foodstuffs are distributed every fifteen days in the camps: wheat flour, dried kidney beans, and sometimes a small portion of oil and sugar constitute the usual rations. Informal markets exist in each of the camps to trade commodities, including tea, cigarettes, spices, cloth, and other household items for those who can afford to buy them. International NGOs provide social, health, and other basic community services. Primary schools in Ifo, Hagadera, and Dagahaley provide elementary education to both refugees and, unofficially, to some of the local population. In a back-handed and perhaps ironic way, the refugee camps in Kenya's Northeastern Province have stimulated economic and social development in the form of jobs and the increased availability of commodities, primary education, and medical services which are offered in the camps. 
By the end of 1996, over half of the refugees that came in 1991 had either repatriated or resettled in a third country. Nonetheless, there are some 190,000 refugees remaining in Kenya, many of whom see no prospects of return to their countries of origin in the near future.

\section{Prima Facie Status in Kenya}

This paper illustrates that the prima facie regime as it has developed over the past few decades for the purpose of protecting refugees in countries, like Kenya, is legally insufficient and sorely lacking in terms of humanitarian standards of practice. We define this regime broadly as determination of eligibility based on first impressions, or in the absence of evidence to the contrary. Some refugees in Kenyan camps have endured living conditions that do not meet the minimum standards set by international refugee law and the International Bill of Human Rights for over five years. ${ }^{15}$ Meeting standards set by these instruments is the issue at hand.

Kenya became a party to the 1951 Convention relating to the Status of Refugees in 1966 and the 1967 Protocol in 1981. The country is also a party to the 1969 OAU Convention Governing the Specific Aspects of Refugee Problems in Africa, which the Kenyan Government ratified in 1992. In Kenya the issue is not the lack of applicable refugee law on an international level. Rather, it is the deficiency in the implementation of the international treaties mentioned above on a domestic level.

There is no national legislation concerning asylum seekers and status determination of refugees in Kenya. A bill was introduced in the Kenyan parliament several times during the $1990 \mathrm{~s}$, but was found too controversial and far-reaching to be accepted by the Government. However, the absence of legislation has not previously prevented Kenya from taking action with respect to asylum seekers. An Eligibility Panel existed to process asylum claims, but it ceased to function when larger numbers of asylum seekers began arriving in 1991. Asylum seekers from Ethiopia, Somalia and Sudan were considered for refugee status on a group basis, whereas other nationalities were left pending as asylum seekers without any legal status being granted to them. All groups, except for individuals accepted under the Convention prior to 1991 as having Convention or 'full' refugee status, are expected to remain in the refugee camps.

In 1992 UNHCR set up procedures for determining refugee status under its mandate in Kenya. This procedure is the only one in place at present, although the Kenyan Government continues to consider the adoption of legislation which would establish a procedure for the

\footnotetext{
Is The International Bill of Human Rights comprises the 1948 Universal Declaration on Human Rights (UDHR48) and the two 1966 Covenants: the Covenant on Civil and Political Rights (ICCPR66), and the Covenant on Economic, Social and Cultural Rights (ICESCR66). Kenya acceded to the Covenants in 1972.
} 
determination of refugee status in Kenya. ${ }^{16}$ Currently, the refugee groups determined on a prima facie basis in Kenya are Somalis and Southern Sudanese who arrive directly from their country of origin to Kenya. ${ }^{17}$ Other African asylum seekers may also be considered on the basis of article 1.2 of the 1969 OAU Convention, which provides that ' $[t]$ he term refugee shall also apply to every person who, owing to external aggression, occupation, foreign domination or events seriously disturbing public order in either part or the whole of his country of origin or nationality', but then only on the basis of an individual determination.

\subsection{Origin and intent of prima facie determination}

Prima facie determination is generally applied in situations of mass movements where individual determination is impractical. In the early days of the 1951 Convention the use of the High Commissioners 'good offices' made it possible to assist refugees in situations similar to that in Kenya. Although the 1951 Convention was drawn up to cover individual claims, there is nothing in the instrument which contradicts the use of group determination or determination on a prima facie basis. ${ }^{18}$ Normally, group or prima facie determination is used where the refugee status of a person is evident on objective grounds. ${ }^{19}$ Under the 1951 Convention, the subjective element of fear can be presumed, ${ }^{20}$ when the situation in the country of origin is such that any person of a particular social group, political opinion, and so forth, would fear persecution. ${ }^{21}$ The Statute of the UNHCR defines to whom the competence of the Office is to be extended. ${ }^{22}$

Despite the individualistic focus of the 1951 Convention as a basis for the grant of asylum, UNHCR was soon engaged in situations where

\footnotetext{
16 The establishment of a procedure would not significantly change the situation of prina facie refugees in Kenya, but the solutions supported in the conclusions of this paper also include local integration. The idea as put forward in Kenya would cover new arrivals and persons not granted prima face refugee status. The possibility of legally being able to integrate into the Kenyan society would thus have to be followed by significant support from UNHCR and the international community.

17 Given political changes in Ethiopia, asylum seekers from that country are no longer considered for prima facie status.

${ }_{18}$ For instance, many States dealing with an influx from the former Yugoslavia adopted specific legislation or administrative measures to implement temporary protection, although some few are dealing with the refugees within the framework of their normal asylum procedures.

19 UNHCR, Note on International Protection 1993: UN doc. A/AC.96/815, para. 27.

${ }^{20}$ According to the UNHCR Handboat on Procedures and Critena for the Detemination of Refuges Slatus, Geneva, 1979, para. 7, '[d]etermination of refugee status will ... primarily require an evaluation of the applicant's statements rather than a judgement on the situation prevailing in his country of origin. However, the term well-founded also provides for support in an objective situation.'

2i See UNHCR, Note on International Protection 1993: UN doc. A/AC.96/815, para. 35; however, arguably a subjective element is needed for group determination under the 1951 Convention.

22 The competence of the High Commissioner extended to persons who fled 'owing to a wellfounded fear of being persecuted for reasons of race, religion, nationality or political opinion' General Assembly res. $428(\mathrm{~V})$, 14 Dec. 1950. The mandate was expanded in subsequent resolutions on an ad hoc basis.
} 
determination of refugee status was needed on a group basis. UNHCR became increasingly involved in working with refugees both in Asia and Africa who were fleeing their countries in large numbers. The main concern in dealing with these large-scale movements was to address the issues of assistance for the people who fled; only later did the action have some legal significance. ${ }^{23}$

In 1956 the High Commissioner for Refugees intervened on behalf of the Hungarians fleeing their country in such large numbers that no individual eligibility determination was feasible. This was the first development in which the High Commissioner assisted groups of refugees, albeit not based on what was later to be called 'good offices'. A resolution adopted by the General Assembly removed any legal and institutional barriers for action. ${ }^{24}$ Resolution 1006 on the Situation in Hungary was a result of the large numbers of refugees obliged to leave Hungary. In article 1 the General Assembly requested the High Commissioner to 'consult with other appropriate international agencies and interested governments with a view to making speedy and effective arrangements for emergency assistance to refugees from Hungary.'

The very first action based on the High Commissioner's discretionary 'good offices' originated in Asia, during the exodus of Chinese refugees to Hong Kong in $1957 .{ }^{25}$ As there were two Chinas, refugees could not be recognized as they had not, strictly speaking, lost protection of their country of nationality. There was an evident grey area in the law. The problem was solved by the General Assembly authorization for the High Commissioner to use his 'good offices' in relation to this group of refugees. ${ }^{26}$ Resolution 1167 authorized 'the United Nations High Commissioner for Refugees to use his good offices to encourage arrangements for contributions', and then later in Resolution 1784 the General Assembly referred to its Resolution 1167 'in which it recognized that the problem of the Chinese refugees in Hong Kong is of concern to the international community...' and requested 'the United Nations High Commissioner for Refugees to continue to use his good offices in agreement with the

\footnotetext{
23 Sadruddin Aga Khan, 'Legal Problems Relating to Refugees and Displaced Persons', Recueil des Cours 1976-I, 287.

${ }^{24}$ UNGA res. 1006 (ESI), 9 Nov. 1956, continued in UNGA res. 1039 (XI), Report of the UNHCR of $23 \mathrm{Jan}$. 1957. In the latter resolution the General Assembly requested the High Commissioner 'to continue his efforts to effect solutions in accordance with the Statute of his Office and the programme of the United Nations Refugee Fund, under due safeguards in accordance with his responsibility under the said statute to provide international protection to refugees within his mandate.'

${ }^{25}$ UNGA res. 1167 (XII), 26 Nov. 1957 and 1784 (XVI), 7 Dec. 1962. See also Guy S. GoodwinGill, The Refuge in Intemational Lang Clarendon Press, Oxford, 2nd ed., 1996, 7-18.

26 Generally on the notion of good offices, see B.G. Ramcharan, Humaritarion Good Offices in Intemational Lar, Intemational Studies in Human Rights, Martinus Nijhof Publishers, Boston, 1983, 44. Goodwin-Gill, Refuget, above note 25, 9-10.
} 
governments of the countries concerned, to provide assistance to Chinese refugees in Hong Kong.'

In the case of Chinese refugees, the High Commissioner was strictly confined to a specific group and therefore had limited scope. Later, the General Assembly authorized assistance through making a distinction between refugees within the mandate and 'refugees who do not come within the competence of the United Nations. ${ }^{, 27}$ The High Commissioner was given a broader mandate in article 2 of Resolution 1388 to 'use his good offices in the transmission of contributions designed to provide assistance to these refugees', that is, the displaced Chinese in Hong Kong. Although two separate groups were identified, they were both being assisted by the High Commissioner.

The concept of 'good offices' thus gave the High Commissioner the flexibility and discretion to assist specified groups of refugees without having to take a position on their legal status or having to expand the definition of a refugee. ${ }^{28}$ The broader scope granted in 1959 extended the use of good offices to be utilized on behalf of any group of refugees who were not formally within the competence of the High Commissioner.

In Africa, the High Commissioner was expressly invited by the General Assembly to assist refugees for the first time in 1959. Refugees from Algeria in Morocco and Tunisia and the Angolan refugees in Congo had been granted refugee status 'en masse', which was not disputed. ${ }^{29}$ Since the 1960 s, prima facie determination has become common if not consistent practice for mass movements of refugees in Africa. The mandate was expanded to include these groups of refugees, but it was also noted that they were refugees of a temporary nature. ${ }^{30}$ Because of the discretionary application of prima facie status, this move has allowed for a politicization of refugee determination processes and the gradual institutionalization of weaker standards of refugee status.

The notion of 'good offices' developed yet further in the early 1960s through UN resolutions concerning Angolan refugees. The relevant resolutions no longer spoke of refugees as being outside the competence of the United Nations, and this in turn provided a more solid base for determination. In addition to broadening the mandate, Resolution 1673

\footnotetext{
27 UNGA res. 1388 (XIV), 20 Nov. 1959.

28 'Refuges: Lessons from the past' Richard Storey Lecture presented by the UN High Commissioner for Refugees, Mrs Sadako Ogata, at St. Anthony's College, Oxford, 5 May 1993.

${ }_{29}$ Sadruddin Aga Khan, above note 23, at 340; UNGA res. 1389 (XIV), 20 Nov. 1959 on Refugees from Algeria in Morocco and Tunisia the General Assembly recommended that the UNHCR should continue his efforts on behalf of these refugees pending their return to their homes'. Reaffirmed in Resolution 1500 (XV), 5 Dec. 1960. In UNGA res. 1671 (XVI), 18 Dec. 1961, on Problems raised by the situation of Angolan Refugees in the Congo, the General Assembly requested 'the High Commissioner to continue to lend his good offices in sending appropriate solutions to the problems arising from the presence of the Angolan refugees in the Republic of the Congo...'

30 UNGA res. $1672(\mathrm{XVT}), 18 \mathrm{Dec}$. 1961, referred to the "temporary nature of the situation of those refugees' in a preambular paragraph.
} 
(XVI) gave the High Commissioner a sweeping basis for action to 'pursue his activities on behalf of refugees within his mandate or those for whom he extends his good offices'. ${ }^{\text {.1 }}$

In 1965, in yet another development, the General Assembly asked the High Commissioner to 'pursue his efforts with the view of ensuring an adequate international protection to refugees and to providing satisfactory permanent solutions to the problems affecting the various groups of refugees within his competence'. ${ }^{32}$ It is on this basis that the work of the High Commissioner has continued, without any authorization being necessary for a particular situation in which she is acting. ${ }^{33}$ It has become a de facto regime under which legal protection and assistance can be provided to refugees fleeing en masse, ${ }^{34}$ where no individual screening is necessary to declare a group of people refugees. ${ }^{35}$

The concept of 'good offices' was developed in conjunction with prima facie determination. Both were pragmatic and strategic, as opposed to legalistic, approaches to the problem of mass human displacement which was becoming increasingly common. Good offices provided a framework for flexible and convenient action. ${ }^{36}$ The intent of the 'good offices' action was clearly to both broaden the legal scope of the refugee definition and to provide assistance to displaced populations. In Kenya, there are no legal obstacles to including prima facie refugees under the refugee definition, as both the 1951 Convention and the 1969 OAU Convention are applicable. The refugees are not granted Convention status, but rather temporary asylum under the prima facie regime.

\subsection{How temporary is temporary?}

In this section, we argue that alternative solutions must be made available to those who are not in a position to return to their home countries after a certain period of 'temporary' asylum. The problem is finding and

31 UNGA res. 1673 (XVT), 18 Dec. 1961, Report of the United Nations High Commissioner for Refugees.

32 UNGA res. 2039 (XX), 7 Dec. 1965, Report of the United Nations High Commissioner for Refugees.

${ }^{33}$ On the extension of UNHCR's mandate, see Goodwin-Gill, Refugee, above note 25; Note on International Protection 1985: UN doc. A/AC 96./660, 6: the High Commissioner's mandate includes 'persons who have fled their home country due to armed conflicts, internal turmoil and situations involving gross and systematic violations of human rights'. In UNGA res. 46/108, 16 Dec. 1991 and 47/107, 16 Dec. 1992, the General Assembly made specific reference to the situation in Kenya.

${ }^{34}$ This goes well together with the purpose of the work of the High Commissioner, which according to para. 2 of the Statute of the Office is to 'relate, as a rule, to groups and categories of refugees'.

35 In some circumstances, however, it may be necessary to interview members of groups to know the background. Individual screening may also be necessary in situations of fraud where asylum seckers pose as new arrivals in order to receive more benefits, and in situations where exclusion of refugees may come into question.

S Sadruddin Aga Khan, above note 23, at 341. 
providing enduring solutions under the relevant instruments. We thus analyse the link between prima facie recognition and temporary asylum. This is an important first step in establishing an argument for further action on behalf of prima facie refugees for whom asylum has become more than a short-term situation. The scenario in Kenya is by no means unique to Africa, but it provides a good example of how prima facie refugees are treated. It illustrates a need for a change in asylum policies, in particular in terms of solutions. It is generally accepted that under conditions of temporary refuge the human rights of refugees may be compromised, but at some point in time the human rights of these often unwanted individuals must be respected. ${ }^{37}$

The original definition of refugee, as outlined in the 1951 Convention, is becoming increasingly irrelevant, particularly in cases of large-scale flows of refugees resulting from ethnic conflicts or other internal disturbances. Put another way, the moral if not legal responsibility for wider categories of persons in need of protection by the international community is becoming increasingly expected. This practice is, however, evidence of humanitarian concern rather than legal obligation. One way that the world community has responded to these crises is through the provision of temporary protection, which allows for group recognition, on the one hand, and an expanded definition of refugee, on the other. ${ }^{38}$ Whether intended or not, the definition of a refugee has expanded as a result of such actions.

In Africa, the need for a more inclusive definition was noted from the inception of the 1951 Convention. Not only did the Convention exclude Africa and other non-European locations until 1967 when the Protocol relating to the Status of Refugees was adopted, ${ }^{39}$ but its definition lacked any provision for protection and assistance to people fleeing armed conflicts, and/or people becoming refugees as a result of internal disturbances during processes of decolonization, democratization and the creation of new States. ${ }^{40}$ The definition of refugee in Africa was augmented to include these conditions for protection and assistance in the Organization of African Unity's own instrument, namely the 1969

${ }^{37}$ In the temporary protection regime it is sometimes argued that in the initial stages only, of temporary protection, can the human rights be limited. UNHCR, Note on International Protection 1993: UN doc. A/AC.96/815, para. 46.

$\$$ See Joan Fitzpatrick, "Flight from Asylum: Trends Toward Temporary "Refuge" and Local Responses to Fonced Migration', 35 Vig. J. Int'l Lano 16 (1994). See also Pierre Bertrand, 'An Operational Approach to International Refugee Protection', 26 Comell Int'l LJ. 501 (1993): 'UNHCR spares no effort to continue to encourage the response of European governments in providing temporary protection to persons flecing conflict in former Yugoslavia'.

\$ The definivion of a refugee adopted in the 195] Convention included an option permitting ratifying States to limit its application to refugecs, in short, whose fear of persecution resulted from events in Europe before 1 Jan. 1951. The 1967 Protocol effectively removed that option, thereby extending the definition to cover the entire world

to Note on International Protection 1994: UN doc. A/AC.96/836, 3, para 3. 
Convention Governing Specific Aspects of Refugee Problems in Africa.

It should be pointed out, however, that prima facie status is a means to avoid recognition under the OAU Convention, which would trigger other obligations from which recognized refugees may benefit under that Convention. Prima facie determination is generally utilized as a temporary designation in Africa because prima facie refugees must reside in refugee camps, and there is normally no access to individual status determination that would grant them the basic rights of a Convention refugee. ${ }^{41}$

Temporary refuge in Africa, as opposed to full Convention refugee status, is sometimes explained by the lack of resources, options, and facilities of the host State. ${ }^{42}$ But some kind of right to temporary asylum is an evolving concept in customary international law, providing that the situation in the country of asylum is 'objectively' considered to warrant the definition of a refugee. ${ }^{43}$ The main difference between the principle of non-refoulement $t^{44}$ and temporary protection in this regard, is that the former has been codified, whereas the latter has not. ${ }^{45}$ Temporary asylum has not yet reached the level of a legal norm by which States agree that they are bound because they are legally required to be so. States simply refuse that there is any kind of right to asylum, regardless of whether it

41 The lack of access to status determination procedures can be contrasted with temporary protection as practised in many Western countries, and UNHCR policy which requires that such access be made available either during or at the end of the temporary period. The 1994 Note on International Protection recognized that there may be some persons unwilling or unable to return when temporary protection is lifted: '[a]s the situation in Bosnia and Herzegovina shows, hopes for an early safe return are not always realized, and at a certain point the refugees' need for stability and greater certainty may call for standards of treatment more appropriate for a prolonged stay, and even eventual conversion to a more definitive status ... Temporary protection, like refugee status, should last as long as there remains a need for international protection (or untu conversion to a more permanent status).' See also General Conclusion on International Protection No. 74 (XLV) 1994, para. (t).

${ }_{42}$ See also Jaan Fitzpatrick, above note 38 , at 57 .

43 Proof of this could be Executive Committee Conclusions 19 (XXXI) on Temporary Refuge and 22 (XXXII) on Protection of Asylum-Seckers in Situation of Large-Scale Influx. There are two sides to the fact that States are creating for themselves a temporary protection regine. Although acceptable as a link to the principle of non-refoulement, it limits the rights to be exercised by the refugees. See in particular Executive Committee Conclusion No. 22, para. I(B), on the treatment of asylum seekers who have been temporarily admitted to a country pending arrangements for a durable solution. See also Deborah Perluss and Joan F. Hartman, 'Temporary Refuge: Emergency of a Customary Norm', 26 Kg. J. Int'l. L 551 (1986). Executive Committee Conclusion 5 (XXVIII) 'appealed to Governments to follow, or continue to follow, liberal practices in granting permanent or at last temporary aglem to refugus who have come dinectly to thai toriton' (emphasis added). The same type of language can be found in Conclusion 19.

44 The description of non-nfoulement in art. 33(1) CSR51 has been developed in art. II.3 OAUR69 Convention: 'No person shall be subjected by a Member State to measures such as rejection at the frontier, return or expulsion, which would compel him to return to or remain in a territory where his life, physical integrity or liberty would be threatened...'A major difference between CSR5I and OAUR69 Convention is that in the latter the protection is granted to any 'person', whereas in the former it is only granted to 'refugees'.

45 Joan Fitzpatrick Hartman, The Principle and Practice of Temporary Refuge: A Customary Norm Protecting Civilians Flceing Internal Armed Conflict', in David A. Martin, ed., The Nao Aglum Seckars: Refuge Law in the 1980s, Kluwer Academic Publishers, Norwell, MA, USA, 1988, 87. 
is temporary or not. Whereas the 'good offices' notion has been primarily a functional and discretionary one, international refugee law - including the OAU Convention and the practice of States to grant temporary asylum - has developed further in that it includes in the definition those who flee internal disturbances. ${ }^{46}$

The temporary protection regime - sometimes called humanitarian, B-status or de facto recognition - as developed in European States may well be compared and linked with the emergence of a customary right to temporary asylum. Prima facie determination has also been used in Western States for granting temporary protection to persons fleeing human rights abuses and internal conflicts as an alternative to individual determination procedures in situations of large-scale flight. It is unclear, however, how prima facie determination is or should be linked to the normal procedures for status determination in those countries. ${ }^{47}$ In Africa, the wider definition of refugee in article I.2 of the 1969 OAU Convention makes it possible to make that link easily.

Temporary asylum can also be used to regularize the status of a group on a temporary basis until individual screening can be carried out. Alternatively, a prima facie determination can be made at the outset after which people can be screened appropriately when the situation permits. ${ }^{48}$ Article II.5 of the 1969 OAU Convention provides that '[w] here a refugee has not received the right to reside in any country of asylum, he may be granted temporary residence in any country of asylum in which he first presented himself as a refugee pending arrangement for his resettlement.... This stipulation provides for a temporary asylum scheme. ${ }^{49}$ The non-refoulement provision in article II. 3 could potentially be linked to the temporary asylum provision. In turn, this might provide some sort of safe haven until a more durable solution has been found..$^{50}$

Other protection strategies, such as the protective zone created by

${ }^{46}$ See art. I.2, OAUR69. On this development, cf. Kay Hailbronner, 'Non-refoulement and "Humanitarian" Refugees: Customary International Law or Wishful Legal Thinking?", in David A Martin (ed.), above note 45, 123.

${ }^{47}$ Note on International Protection 1993: UN doc. A/AC.96/816, para. 26.

${ }^{48}$ See UN doc. EC/SCP/22/Rev.1, 3 Sept. 1982, Follow-up on Earlier Conclusions of the SubCommittee on the Determination of Refugec Status, referring to the role of UNHCR in national refugee status determination procedure. It also declares that 'In such cases regard is had to the objective circumstances that led the group to leave the country of origin, in order to determine whether the members of the group qualify for imermediate protection pending an individual examination of their case or can - in the absence of indications to the contrary - be presumed to be refugees.'

49 The argument for temporary asylum pending other durable solutions is not unfamiliar, however, and was the only means for UNHCR to assist Indochinese refugees in many Asian countries, as those States had not ratified any of the relevant legal instruments.

${ }^{30}$ See Jennifer L. Turner, 'Libertan refugees: A test of the 1969 OAU Convention Governing the Specific Aspects of Refugee Problems in Africa', $8 \mathrm{Gs}$. Imm $L J .282$ (1994); the author appears to argue that the non-refoulement provision may provide temporary refuge to those who do not fit within the expanded $O A U$ definition. 
UNHCR for the Cross-Border Operation, are commendable in their efforts to assist displaced people 'at home', but they arguably weaken refugee protection in an orthodox sense if accepted as temporary solutions in particular cases. For instance, in the case of Kenya a new influx of Somali refugees arrived during the first half of 1996. The Government of Kenya (GOK) stopped several thousand potential asylum seekers at the border and insisted that UNHCR should - in the spirit of CBO create a kind of safe zone on the Sormalian side of the border. The Government maintained that UNHCR should assist these asylum seekers as internally displaced persons. The Government co-opted the language and strategy of multilateral organizations - of the UN in particular to argue for a 'preventive zone' inside Somalia instead of allowing forced migrants to enter Kenya as refugees. This move on the part of the Kenyan Government signals a potential shift in responsibility for displaced persons from individual nations to multilateral organizations, and from assisting displaced persons as refugees to helping them at home before they cross an international border. Where this option is not politically or practically feasible, prima facie refugee status is the minimum provision for forced migrants. It allows host countries, such as Kenya, to avoid the obligations and entitlements which accompany Convention refugee status.

The quasi-protective measures of prima facie status, in conjunction with safe havens and 'preventive protection' for the internally displaced, have worked to undermine the emerging right to temporary asylum, and, in particular, the principle of non-refoulement. The governments of first countries of asylum, as well as donor and resettlement nations, are interested in assisting and protecting displaced persons on the other side of the border, at home, if that option is made available to them. The refugee situation in developing countries, however, can be seen as a quid pro quo situation, whereby the hospitality of the past will likely be reciprocated in the future. The tendencies of governments to undermine the evolving customary norm of non-refoulement have been loudly opposed, in most cases, by the High Commissioner and her staff. The forced return of Kurdish refugees at the Turkish border and Rwandese and Burundi refugees at the Tanzanian border serve as examples.

In terms of possible solutions for prima facie refugees who have been residing in a country of asylum for a long period, the 1969 OAU Convention also makes specific reference to voluntary repatriation in article $\mathrm{V}$. This is not the case of the 1951 Convention, although the Convention makes specific reference to the cessation of refugee status. Volition for voluntary repatriation must come, of course, from the displaced person. In the majority of cases, voluntary repatriation is the only available solution for prima facie refugees. Although prima facie status is granted on an objective basis, repatriation is not determined on the same terms. ${ }^{51}$

${ }^{31}$ Note art. V.1, OAU69: "The essentially voluntary character of repatriation shall be respected in all cases and no refugee shall be repatriaied against his will.' 
Where do we go from here? Can the principle of non-refoulement be derogated from? Providing no other options to prima facie refugees who cannot return ultimately makes the nature of repatriation forced. Temporary protection is dependent on the objective situation in a given country, but consideration of refugees who are not in a position to return is also critical..$^{52}$ For a prima facie refugee in a Kenyan camp, at what point might such alternative solutions take effect? Is, say, five years enough to warrant a more permanent solution?

In our view, the human rights of refugees in Kenya are being exchanged for their temporary asylum in camps. The question, how temporary is temporary protection, cannot simply be answered in the context of a specific time period. States and the UNHCR must adopt a more proactive approach to improve the situation for refugees who are not able to return; it is a question of improving the situation of prima facie refugees progressively over time. Although these refugees have not been granted status under any legal instruments, certain standards nonetheless apply to all people, citizens or refugees.

\subsection{Human rights and prima facie refugees in Kenya}

Recognizing that human rights for temporary asylum and/or prima facie refugees can be limited ${ }^{53}$ and that the principle of non-refoulement is not about providing durable solutions to refugees, ${ }^{54}$ the fact remains that the term 'temporary' has, in Kenya, become a misnomer. The experience of refugees in the Dadaab camps is anything but temporary. Limitations on and derogations from international human rights instruments as they apply to refugees are to be employed in special circumstances and for a limited period of time. ${ }^{55}$ For refugees in Kenya who have been restricted to the space of the camps for more than five years, there is a point at

52 For instance, the Dayton Agreement on Implementing the Federation of Bosnia and Herzegovina, 10 Nov. 1995, has been used as an argument to lift temporary protection in that it provides for a plan for the return of refugees and displaced persons in its Section $E$. The argument being that now the objective situation of fear has ceased to exist and refugees may return home.

${ }_{53}$ See Note on International Protection 1994: UN doc. A/AC.96/836, para. 1. This topic was also discussed in 1981 in the UNHCR Executive Committee Sub-Committee on the Whole on International Protection on the basis of the report of Group of Experts on temporary refuge in situations of large-scale influx; this in turn led to the adoption of Conclusion No. 22 (XXII) on the protection of asylum seckers in such situations.

It Guy S. Goodwin-Gill, 'Non-Refoulement and the New Asylum Seekers', in David A. Martin, ed., above note 45, 103; and for later reflection on this issue, Goodwin-Gill, G.S., The Refuger in Intemational Lau, Clarendon Press, Oxford, 2nd ed, 1996, ch. iv.

${ }^{35}$ See ar. 12. Derogations provided for in art. 4 in times of public emergency are also subject to limitations, including informing the Secretary-Ceneral about the derogations. See Ninth Annual Report and list of States which, since I Jan. 1985, have proclaimed, extended or terminated a state of emergency: 'Kenya: According to a non-governmental source, a long-term state of emergency has been in effect in the north-eastern part of the country until the beginning of 1992. The Special Rapporteur awajis more precise information to be submitted by the Government, cspecially with regard to the emergency-type detention law currently in force.' UN doc. E/CN.4/Sub.2/1996/19, 18 Jun. 1996. 
which their condition can no longer be considered temporary. We argue that the suspension of certain human rights, such as the freedom of movement, the right to gainful employment, and right to education, cannot continue indefinitely. Over time, refugees require solutions which allow them to create quasi-independent livelihoods when there appears to be no solution in sight for the refugees. ${ }^{56}$

In practice, protection measures in Kenya have developed in a similar way to the temporary protection regime in Europe. ${ }^{57}$ Refugees from the Former Yugoslavia fleeing civil war found themselves accorded temporary protection in European States with limited rights to employment, social welfare, and so forth. The temporary protection regime in Europe includes respect for a minimum level of human rights. Yet, these same rights in Kenya are much more basic than the refugee rights referred to in Europe. This is one of the reasons why Kenya has chosen not to process Convention refugees; refugees would then have a right to compete with Kenyans on the labour market. It is indeed positive that Kenya to date has largely respected the rights of the Convention refugees who received their status prior to 1991.

Kenya acceded to the two Covenants on Economic, Social and Cultural Rights, and Civil and Political Rights in 1972. The Government has also ratified the African Charter on Peoples' and Human Rights which is a comprehensive regional human rights instrument covering the whole variety of human rights at once. There is no lack of applicable international law in Kenya, but the mere ratification of these instruments is clearly not - enough to generate action and improvements on the ground. Current modes of implementation fail to provide alternative solutions when temporary asylum becomes a long-term condition.

\subsection{Government 'round-ups' of refugees}

Prima facie refugees in Kenya are required by the Government to reside only in refugee camps, though not all of them do. The Government of Kenya (GOK) has not hidden its disdain for Somali refugees living in Kenya, nor for its own Kenyan nationals of Somali ethnicity. Racism

56 Art 2(1) provides: '[c]ach State Party to the present Covenant undertakes to take steps, individually and through international assistance and co-operation, especially economic and technical, to the maximum of its available resources, with a view to achieving progressively the full realization of the rights recognized in the present Covenant by all appropriate means, including particularly the adoption of legislative measures.' Art. 39 of the 1989 Convention on the Rights of the Child includes measures with regard to reintegration and recovery for the child victim of armed conflicts. As all provisions of the Convention apply to all children, this article is significant in that the obligation entailed is fairty comprehensive in providing 'solutions' for war-affected children. See further, Bo Viktor Nylund, "International Law and the Child Victim of Armed Conflicts - Is the "First Call" for Children?', forthcoming in the Intermational Joumal of Childron's Rights (1998).

5) For a similar situation with the temporary asylum concept in Europe, see Joanne Thorburn, 'Transcending Boundaries: Temporary Protection and Burden-sharing in Europe,' 7 IJRL 477 (1995); Goodwin-Gill, Refigee, 199-202. 
and discrimination against Somalis refugees, for example, are practised today just as they were during the colonial period in which Britain ruled Kenya and Northern Somalia, France controlled Djibouti, and Italy occupied Southern Somalia. The programme of the Kenyan Government in the late 1980s made life grim for Somalis from either side of the border. State-of-emergency laws in the area allowed for up to fifty-six days detention without trial. Harassment, beatings, and torture of Somalis were reported.

The Kenyan authorities are also using the influx of Somalis seeking sanctuary to impose a discriminatory and repressive screening process on its own ethnic Somalis community, which has suffered a history of persecution ... The arrival of the refugees is being used as an opportunity to impose compulsory screening on all Kenyan-Somalis, in order to identify 'illegal aliens. ${ }^{58}$

Otunnu Ogenga adds that the screening process, combined with the strategy of keeping Somalians in camps and involuntary repatriation, forms an unstated policy of 'refugee deterrence'. ${ }^{59}$ On 16 June 1991, hundreds of Somalis were rounded up by Kenyan authorities for screening; a subsequent report noted that

On the weekend of August 15/16, the police burst into the temporary homes of 2,000 Somali and Ethiopian refugees in Nairobi and Mombasa, rounded them up, forced them to board lorries at gun point after which they were driven to refugee camps. Families were separated and many small children left abandoned. The police were apparently in search of any 'Somali-looking person' in areas with large groups, such as Eastleigh (a Nairobi suburb), South $\mathbf{C}$ and Koma Rock. ${ }^{60}$

It is ironic, given this situation, that the word 'asylum' - which is derived from the Greek asylon - means 'something not subject to seizure' or 'freedom from seizure. ${ }^{61}$ Many Somali asylum seekers did not find sanctuary in Kenya. Instead they were the targets of racist raids and random removal to a country to which some had never been. Again in August 1992 and in August 1993, Kenyan authorities rounded up refugees living in urban areas and purposefully transferred them to remote camps and border sites located in the Northeastern Province. ${ }^{62}$ The Government refused to allow UNHCR to house any refugees in Central Kenya.

As noted, refugees in Kenya are confined to refugee camps and

58 Africa Watch, New York, 17 Nov. 1989, 10-11 (source: UNHCR REFINFO database).

s9 Otunnu Ogenga, 'Factors Affecting the Treatment of Kenyan-Somalis and Somali Refugees in Kenya: A Historical Overview', Refuge, vol. 12, no. 5, Dec. 1992, 21-5.

fio Africa Events, London, Sept. 1992, 8 (source: UNHCR REFINFO database).

${ }^{61}$ Rosemary Rogers \& Emily Copeland, Foned Migration: Poligy Issues in the Post-Cold War Wortd, Massachusetts, Tufts University, 1993.

6 Netherlands Development Corporation, 'Humanitarian Aid to Somalia, Evaluation Report 1994', Den Haag, 1994. 
vulnerable to arrest if living outside the camps. ${ }^{63}$ Again, in December 1995 thousands of refugees and aliens were arrested by the police outside refugee areas and held well beyond the constitutional 14 days. This was a direct result of the Kenyan policy that all refugees should reside in the camps. Many refugees prefer staying in the urban areas which offer access to better education, security, and comfort. The security situation in the Dadaab camps in the Northeastern Province in Kenya is deplorable. Refugees face banditry, rape and violence on almost a daily basis. This situation is also what triggered the Women Victims of Violence project, launched by UNHCR in 1993. That project significantly improved the security situation and found solutions for women who were victims of such violence, highlighting the fundamental right not only to education and freedom of movement, but also to security of person. Dadaab is arguably evidence of the cruelty and folly of warehousing people for years on end. The refugee camps of Ifo, Hagadera and Dagahaley are all located in hot, arid areas with little access to the attractions of secondary schools, informal labour markets, and particular goods and services.

Article 26 of the 1951 Convention provides that ' $[\mathrm{e}]$ ach Contracting State shall accord to refugees lawfully in its territory the right to choose their place of residence and to move freely within its territory, subject to any regulations applicable to aliens generally in the same circumstances. ${ }^{64}$ As there are no regulations applicable to aliens in Kenya, arguably there should be none to refugees either. This stipulation, however, does not apply to non-Convention, that is, prima facie refugees. They are, in a sense, the human objects of a containment strategy to isolate and control displaced populations.

The right to freedom of movement was first recognized by the Universal Declaration on Human Rights. While not a binding treaty, the Declaration has gained worldwide recognition as a minimum human rights standard. The language which frames freedom of movement was codified in article 12(1) of the Covenant on Civil and Political Rights, which provides that '[e] veryone lawfully within the territory of a State shall within that territory, have the right to liberty of movement and freedom to choose his residence.' Article 12(3) of the Convention on Civil and Political Rights provides for a limitation by stating that,

the above mentioned rights shall not be subject to any restrictions except those which are provided by law, arc necessary to protect national sccurity, public order (ordre public), public health or morals or the rights and freedoms of others, and are consistent with the other rights recognized in the present Covenant. ${ }^{65}$

\footnotetext{
6 U.S. Department of State, 'Kenya Human Rights Practices, 1995', Washington D.C., March 1996.

${ }_{\text {GH }}$ Ar. 12 of the African Charter contains a similar provision.

65. The limitation applies to restrictions provided by law, and should be understood stricto sensu.
} 
As there is no such law in place, restricting refugee movement is clearly a violation of Kenya's obligation under the 1966 Covenant on Civil and Political Rights.

The UNHCR's Executive Committee's Conclusion 22 (XXXII) of 1981 also provides protection with regard to freedom of movement. It ensures that asylum seekers admitted temporarily 'should not be subjected to restrictions on their movements other than those which are necessary in the interest of public health and public order.' Increased criminality in Kenya has often been linked to the high number of refugees in urban areas. This provides the Kenyan Government with a policy rationale for keeping refugees in designated camps; it is deemed necessary for internal security. While not legally binding, conclusions adopted by the Executive Committee of the UNHCR offer some guidance on minimum standards applicable to refugees. ${ }^{66}$ Confining refugees to camps is highly questionable as 'necessary' to public interest.

\subsection{The right to education}

Restricted mobility results in a difficult situation for refugees who seek access to other basic needs protected by human rights, such as education. According to article 22 of the 1951 Convention, the State is required to provide treatment, as favourable as that accorded to nationals, with regard to elementary education. Refugees are supposed to be treated as aliens for higher education. Article 13 of the Covenant on Economic, Social and Cultural Rights - to which Kenya is a signatory - also provides a right to education. ${ }^{67}$ Primary education is to be compulsory, available, and free to all. The nature of such a right is progressive; that is, it is to be arrived at over time. Under article 2 of the Covenant on Economic, Social and Cultural Rights, States commit themselves to the progressive achievement of rights set forth in the Covenant.

As noted above, the right to primary education is guaranteed to refugees who are staying in the camps. Schools and staff are provided by the UNHCR. Through a special agreement arrived at between the Kenyan Government and UNHCR, refugees with the means to fund education or employment training programmes in the cities may be granted special permission to partake in these activities on a temporary basis. The

\footnotetext{
${ }^{66}$ Art. 31 CSR51 contains provisions on treatment of refugees whose situation has not yet been regularized. Those standards do not, however, cover all aspects of treatment of asylum seekers in large-scale movements. Conclusion 22 therefore provided for a set of minimum basic human standards.

${ }^{67}$ Art. 28 CRC 89 also provides that the child has a right to education, and that with a view to achieving this right progressively States are to make primary education compulsory and available free to all. All rights in CRC89 apply to all children within the jurisdiction of the State Party. The Committee on the Rights of the Child, commenting on the reports of State parties, has emphasized the importance of the right to primary education. Art 17 of the Africa Charter on Human and Peoples' Rights also provides that 'Every individual shall have the right to education.'
} 
significant number of refugees who decide to remain in or move to the urban areas must do so without a UNHCR subsidy for studies in the urban areas for primary education. While a number of NGOs do provide scholarships for primary education in urban areas, those who are in a position to live in the city are generally the more affluent refugees. This arrangement creates a de facto segregation of poorer refugees in the camps and wealthy ones who can afford to be financially independent in the cities.

Freedom of movement is a civil right, and is therefore instant in its application. ${ }^{68}$ The fact that it is linked to social and cultural rights, such as the right to education, also gives the situation a.progressive element. ${ }^{69}$ This puts an obligation on the Government of Kenya to seek solutions to the situation, but also on UNHCR, other agencies, and the international community to at least notice and address the problems.

Whereas root causes and possible solutions to refugee flows are the focus of much attention, comparatively little effort has been invested in protecting the rights of refugees who have sought refuge and are unable to return. While there is no right to asylum as such, there are standards to be respected once it has been granted. ${ }^{70}$ Recognition must also be given to the fact that there may be circumstances under which refugees are not contemplating returning to their country of origin, and therefore must be able to enjoy their human rights in the place that they have taken refuge. If this is not possible - and developing countries like Kenya will have difficulty in ensuring, for example, economic rights alternative solutions must be seriously considered.

\subsection{Posing alternatives}

Both UNHCR and the international community must sooner or later pay attention to the condition of prima facie refugees in limbo. ${ }^{71}$ For those residing in refugee camps, their lives are literally put on hold: they cannot move outside the camps; many cannot seek education beyond primary

\footnotetext{
${ }^{68}$ Art. 2(I) provides that '[e]ach State Party to the present Covenant undertakes to respect and to ensure to all individuals within its territory and subject to its jurisdiction the rights recognized in the present Covenant'.

69 According to art. 2(l), '[e]ach State Party to the present Covenant undertakes to take steps, individually and through international assistance and co-operation, especially economic and technical, to the maximum of its available resources, with a view to achieving progressively the full realization of the rights recognized in the present Covenant by all appropriale means, including particularty the adoption of legislative measures.'

${ }^{7}$ Note in particular art. 14 UDHR48, which provides that ' $[E]$ veryone has the right to seck and to enjoy in other countries asylum from persecution. This right may not be invoked in the case of prosecutions genuinely arising from non-political crimes or from acts contrary to the purposes and principles of the United Nations.

7 Note on International Protection: UN doc. A/AC.96/850, 1 Sep. 1995, 2, International Protection in Mass Influx. Para. I of the UNHCR Statute provides that the UNHCR shall seek 'permanent solutions for the problem of the refugees...'
} 
school; and employment is precluded because of their status. This situation of stagnation and dependence is deplorable. Moreover, it defies the standards set out in human rights instruments and international refugee law outlined above. Our call for action does not suggest a lessening of the responsibility of host governments. On the contrary, it requires their active cooperation.

As Guy Goodwin-Gill points out, while the UNHCR mandate has certainly been expanded to include new groups of people, it has not been expanded to include new solutions. ${ }^{72}$ The Addis Ababa Document of Refugees and Forced Population Displacements in Africa, adopted in September 1994, represents one step in the right direction. The document was adopted 'with a view to elaborating a Comprehensive Plan of Action.' The Conference arrived at some progressive recommendations from which the refugree situation in Africa may benefit, such as the idea of international burden-sharing. This document contains a number of good ideas to be revisited by the international community and international organizations, some of which are discussed below.

Good ideas require political will and resources to enact. Policies may exist, but their application is lacking. ${ }^{73}$ The legal obligation is sufficient, but there is a need to mobilize political will to implement that obligation. Africa hosts a greater proportion and greater numbers of refugees and displaced persons than any other world region. Yet, the resources of African countries to provide for refugees are comparatively modest. Countries of the Global North have been generous in their support of refugees in African locations, but simply paying for 'care and maintenance' to enable refugee subsistence is not a solution after years of camp life have passed. The challenge of the international community to take responsibility for improving these crises of displacement has never been greater. Any effective solution must take seriously the possibilities of global cooperation and burden-sharing. ${ }^{74}$ Even territorially-circumscribed solutions, based in law, history and the practices of particular regions, require the support - both material and political - of the more industrialized countries.

While the idea is not new, a measure of burden-sharing to improve conditions in countries of asylum is required if refugees are to enjoy the most basic human rights and protection. Alternative solutions depend upon international cooperation, the current lack of which remains an

\footnotetext{
72 Guy S. Goodwin-Gill, 'Asylum: The Law and Politics of Change,' 7 IJRL I (1995).

73 'UNHCR, lssues and Challenges in Intemational Protection in Africa', IJRL OAU/UNHCR Spectal Issue 55 (1995)

${ }^{74}$ James C. Hathaway \& R. Alexander Neve, "Toward the Reformulation of International Refugee Law: A Model for Collectivized and Solution-Oriented Protection', discussion paper prepared by the Refugee Law Research Unit of the Centre for Refugee Studies, Yort University, Toronto, Canada, Sept. 1996.
} 
obstacle to developing a more responsive regime of international protection. ${ }^{75}$ The establishment of safe havens and UN protected areas within countries in conflict is not a sufficient response. It remains the role of the international community to share responsibility with countries of first asylum which are receiving the lion's share of refugees. ${ }^{76}$ This is the spirit of the 1969 OAU Convention. Owing to lack of funds and fewer resources in first countries of asylum, the local integration aspect of durable solutions needs the support of the international community. ${ }^{77}$ In legal terms this could mean reliance on article II.4 of the OAU Convention when it comes to 'long-stayers'. Article $\Pi .4$ provides for burden-sharing and international cooperation between OAU member States. The Addis Ababa Document also underscores efforts to enable refugees to regain a normal way of life. ${ }^{78}$

The idea of intra-African resettlement of refugees has also been proposed. In the Addis Ababa Document, the symposium appeals to African States to offer places to refugees from other African countries for resettlement. ${ }^{79}$ While this potential solution cannot be realized without the material support of traditional donor countries, it is worth exploring the modalities of such resettlement options in greater detail. One strong argument that has been made in favour of this particular solution is its potential to decrease the current brain-drain problem. This argument was often voiced by the refugee community in Kenya. Such a solution, however, should not be viewed as a strategy to regionalize the 'refugee problem.' The current trend in major resettlement countries towards reducing the numbers of refugees admitted only exacerbates the lack of more permanent solutions for those in camps.

\section{Conclusions}

Years of living in Kenyan camps has certainly become more than a temporary solution for Somalian, Sudanese, and Ethiopian refugees. There is a trend towards camp-like solutions on the part of UNHCR in the Horn of Africa. The agency is putting most of its efforts into finding group-solutions, in particular voluntary repatriation, which is laudable if

\footnotetext{
75 Note on International Protection: International Protection in Mass Influx, para 14: UN doc. A/AC.96/850, 1 Sept. 1995.

${ }_{76}$ For comparative analysis, see Joanne Thorburn, 'Transcending Boundaries: Temporary Protection and Burden-sharing in Europe', 7 IJRL 461 (1995).

$"$ UN doc. A/AC.96/850, para. 18. The Plan of Action adopted in Bujumbura at the Regional Conference on Assistance to Refugees, Returnees and Displaced Persons in the Great Lakes Region of February 1995 includes a statement of actions needed from the international community.

${ }^{78}$ See Addis Ababa Document, Recommendation 7, which mentions that States should enable refugees to regain a normal way of life. Recommendation 11 makes an appeal for genuine international solidarity and burden-sharing, for text, see IJRL OAU/UNHCR Special Issue, 301 (1995).

${ }^{79}$ Addis Ababa Document, above note 78, Recommendation 23.
} 
it is really possible. The increasing permanence of UNHGR's camp operations in locations like Dadaab, however, where UNHCR protects over 100,000 mostly Somali refugees, is problematic. UNHCR tends to maintain refugees in camps, at the Kenyan Government's insistence, at the expense of basic human rights including freedom of movement and the right to employment. Camps are low-cost and localized, but they are not always temporary responses to forced migration. In legal terms, emphasis is being placed not on asylum, but on non-refoulement. Nonrefoulement may be the most important principle of refugee law, but it is inadequate in and of itself to address the massive scale of displacement and the conditions of those uprooted by these crises.

There is a clear and present danger that governments, like that of Kenya, will co-opt the strategic language of 'preventive zones' and safe havens in an effort to shirk their responsibilities to refugees. This move signals a potential shift in responsibility for displaced persons from individual nations to multilateral organizations, and from assisting displaced persons as refugees to helping them at home before they cross an international border.

We maintain that ad hoc discretionary measures to assist refugees are too fickle and politically-driven to ensure any consistency in humanitarian provisions and human rights enforcement. Fairness and consistency are predicated on benchmarks of entitlement determined by consenting parties, or States. The Human Rights Covenants and international laws pertaining to refugees and other displaced persons change at a glacial pace in response to new social, economic, and political conditions. Nonetheless, the importance and application of both humanitarian and human rights instruments must be revived to avoid impromptu, piecemeal provision of assistance to displaced persons whose strategic value to 'First World' States has waned in the post-Cold War period. These laws and instruments remain useful, if insufficient tools because they are historically contingent and geographically inclusive.

To achieve fairness and consistency, a continued and critical contribution on the part of UNHCR is required. The organization is well positioned to engage in the development of more permanent solutions for prima facie refugees. Not only can UNHCR enhance its present role by providing assistance appropriate to specific sites of human displacement, but the organization - in cooperation with other UN agencies, such as the Office for the Co-ordination of Humanitarian Affairs and the UN High Commissioner for Human Rights - is in a position to advocate changes to pertinent international conventions and laws and to introduce new measures where necessary. UNHCR has already begun this work, for example, in conjunction with the Special Representative of the UN Secretary-General on Internally Displaced Persons, by addressing ways 
to assist internally displaced people..$^{80}$ Increased collaboration between High Commissioners would be useful, as the Office of the UNHCR has extensive 'on the ground' knowledge of human rights in the countries in which it is present. There is always need for more detailed country of origin information, a role for which the High Commissioner for Human Rights would be most suitable. ${ }^{81}$

The effects of war are still being felt in Somalia and Sudan. In turn, Kenya will continue to harbour refugees from those countries. In June 1996, some 2,300 new Somali refugees arrived at Liboi, near the KenyaSomalia border. ${ }^{82}$ 'The international community and international human rights monitors have repeatedly reported that the situation in Somalia continues to deteriorate and thousands of Somalis continue to be killed and displaced. ${ }^{83}$ For many of the refugees living in Kenya, reports such as this suggest that repatriation is not possible given political conditions at home. For this group of refugees, more permanent solutions and independent livelihoods must be sought.

In the African context, individual case determination for refugees, based on the 1951 Convention and 1967 Protocol and the 1969 OAU Convention has largely been supplanted by group status designations based on the regionally-specific refugee definition outlined in the 1969 OAU Convention. It has not, however, been followed by the rights to which Convention refugees are entitled. The expanded definition of the OAU Convention was a protection measure to complement the refugee definition of the 1951 Convention. As it has turned out, the definition of article 1(2) of the OAU Convention has also been the basis for granting refugee status on a prima facie basis in Africa. The status was never intended to be used alone because it does not stipulate conclusive action nor solutions for refugees designated as such.

In the Horn of Africa, recognized groups of displaced persons outside their home country are generally accorded prima facie refugee status and are administered and assisted by UNHGR and partner NGOs. This analysis has demonstrated that prima facie status offers few, if any, political solutions to refugees. Somali refugees in Kenya with prima facie status are spatially segregated and isolated in remote border camps. In the absence of the kind of legal status accorded to Convention refugees, or some other regional alternative, their mobility is restricted. While all refugees

\footnotetext{
${ }^{80}$ Francis M. Deng, 'The International Protection of the Internally Displaced', IJRL OAUI UNHCR Special Isoue, 74 (1995); and UNHCR, UNHCR' Operatonal Experience with Intemally Displaced Pasons, Geneva, Sept. 1994; Roberta Cohen, 'Intemational Protection for Internally Displaced Persons - Next Steps', Focus paper no. 2, Refugee Policy Group, Washington D.C., Jan. 1994.

${ }^{81}$ It is the responsibility of UNHCR and the UN High Commissioner for Human Rights to mobilize the forces for continued peace in the country of retum. Both require political and material support to mount these operations.

E-mail correspondence, UNHCR Branch Office Nairobi, 7 Jun. 1996.

83 Canadian Council for Refugees, 'Resolutions', 1 Jun. 1996, Section IV, Resolution 18.
} 
are subject to the laws and responsibilities of the State in which they reside, they are not criminals, nor prisoners, simply because they have been forced to move.

While the locations and conditions of Kenyan refugee camps are not desirable by any standard, the most important criticism of them is their very conception as potentially long-term segregated 'safe spaces' for refugees. As anything more than an immediate, emergency response to an unexpected influx of displaced people, camps are not satisfactory solutions. They can provide short-term safety, but they also institutionalize long-term exclusion, marginalization, and waste of both human and financial resources. UNHCR has already recognized that 'so long as reform continues in an ad hoc manner, it will remain prey to the limitations and contradictions of piecemeal change. ${ }^{84}$ This conundrum is perhaps the greatest challenge to effective humanitarian operations and refugee protection since the end of the Cold War.

84 UNHCR, 'Issues and Challenges in International Protection in Africa', IJRL OAU/UVHCR Special Isrue, 55, at 67 (1995). 